\title{
COVID-19, Cities and Urban Informal Workers: India in Comparative Perspective
}

\section{Martha Chen ${ }^{1}$}

Published online: 23 September 2020

(c) Indian Society of Labour Economics 2020

\section{Introduction}

Informal workers represent $61 \%$ of all workers globally-a total of 2 billion workers worldwide (ILO 2018). Of these, an estimated 1.6 billion-80\%-could see their livelihoods destroyed due to the lockdowns and related shelter-at-home restrictions in response to COVID-19 (ILO 2020). Since long before the COVID-19 virus hit, informal workers have been struggling for justice, equality and dignity as workers and as human beings in large part because they are widely stigmatized by economists and policy makers as illegal and non-productive, while most are trying to earn an honest living under a very harsh policy and regulatory environment. The current COVID-19 crisis - both the pandemic itself and the policy response to ithas shown a spotlight on the fact that many of the frontline workers who provide essential goods and services-health, food, child care, transport-are informally employed as well as the injustices, inequities and indignities that informal workers face.

The current COVID-19 moment presents a unique opportunity to support informal workers in their struggle for justice, equality and dignity. But it also presents both old and new threats to informal workers. This paper makes the case for a Better New Deal for informal workers, with a focus on cities and urban informal workers, while recognizing the very real risk that governments, the private sector and policy makers will revert to the Bad Old Deal or introduce a Worse New Deal for informal workers.

This paper opens with a summary of the first-ever global estimates of informal employment (ILO 2018) putting India in a comparative global perspective. It then presents the cases of street vendors and waste pickers to illustrate how cities have treated informal workers pre-COVID and during COVID-19: sharing two promising examples each, one from India and the second from elsewhere, of how street vendors and waste pickers could be better treated going forward. It concludes with

Martha Chen

Martha_Chen@hks.harvard.edu

1 WIEGO Network, Harvard University, Cambridge, USA 
Table 1 Informal employment as a share of total and urban employment: World, India and country income groups. Sources: Global-ILO 2018, Bonnet et al. 2019 and IndiaPLFS 2017-18, analysed by G. Raveendran

\begin{tabular}{lll}
\hline $\begin{array}{l}\text { World, India and countries by } \\
\text { income level }\end{array}$ & Total & Urban \\
\hline World & 61 & 44 \\
Developing countries & 90 & 79 \\
India & 90 & 79 \\
Emerging countries & 67 & 51 \\
Developed countries & 18 & 17 \\
\hline
\end{tabular}

Table 2 Self-employment and wage employment as shares of informal employment: World, India and countries income groups. Sources: Global-ILO 2018, Bonnet et al. 2019 and India-PLFS 2017-18, analysed by G. Raveendran

\begin{tabular}{lll}
\hline $\begin{array}{l}\text { World, India and countries by } \\
\text { income level }\end{array}$ & Self-employment & $\begin{array}{l}\text { Wage } \\
\text { employ- } \\
\text { ment }\end{array}$ \\
\hline World & 64 & 36 \\
Developing countries & 79 & 21 \\
India & 56 & 44 \\
Emerging countries & 63 & 37 \\
Developed countries & 49 & 51 \\
\hline
\end{tabular}

reflections on how the relief to recovery transition in policy responses to COVID-19 presents both an opportunity for positive transformation and a risk of negative reversals for informal workers.

The sources of statistical data are, globally, the ILO 2018 estimates of informal employment (as summarized in Bonnet et al. 2019) and, for India, analysis of the 2017-18 Periodic Labour Force Survey (PLFS) by Raveendran (forthcoming in Raveendran and Vanek 2020). The sources of non-statistical evidence on the impact of COVID-19 on informal workers are an early rapid appraisal, on-going contacts with organizations of informal workers and preliminary findings of a 12-city study by the Women in Informal Employment: Globalizing and Organizing (WIEGO) network.

\section{Latest Statistics on Informal Employment}

In 2018, the ILO published the first-ever global estimates of informal employment. In early 2020, Govindan Raveendran, former Additional Director General of the Central Statistical Organization of India, generated updated estimates of informal employment in India based on the 2017-18 national PLFS (Raveendran forthcoming). Table 1 shows that the size and significance of informal employment in India equals the average for developing economies, although India is an emerging economy.

Table 2 shows the composition of informal employment by self-employment and wage employment. It shows that self-employment is far less significant among informal workers in India than on average in developing countries and even less than on 
average in emerging economies. The relatively high prevalence of informal wage employment points to the significance of informal wage employment in formal firms and for households, not just in informal enterprises.

\section{Two Urban Cases}

\subsection{Street Vendors and Market Traders}

Informal trade by street vendors and market traders plays a critical role in food security. One study of 11 cities in sub-Saharan Africa found that $70 \%$ of households in low-income areas in those cities normally source food from informal traders: around one-third buy food from informal traders on a daily basis and two-thirds at least once a week (Crush and Frayne 2011). In India, around $90 \%$ of food retail trade is by street vendors or small grocery (kirana) shops (see Sudha Narayan this volume).

Before COVID-19 in most cities around the world, street vendors faced harassment, bribes or confiscation of goods on a daily basis and evictions on a regular basis. Only a few cities recognized and valued street vendors for their contribution to food security and the local economy and protection of the natural markets where street vendors have congregated for decades, if not generations. During lockdown or other restrictions in response to COVID-19, most cities did not allow street vendors to operate. But some cities allowed street food vendors to operate, especially those who sell fresh fruits and vegetables.

Two examples of government support to street food vendors during COVID-19, one by the national government of South Africa and the other by a city government in India, suggest pathways to a better deal for street vendors post-COVID. Seven days into its COVID-19 lockdown, in response to pressure from civil society including local members of the WIEGO Urban Policies team, the Government of South Africa declared informal food vendors to be essential service workers. In consultation with public health experts, WIEGO prepared health safety guidelines (circulated on WhatsApp) for informal traders, including the provision of water points, sanitizers and bleach, safe layouts and testing. Public health experts in South Africa concluded that, as long as these health safety guidelines are followed, informal traders can trade as safely as super-markets (Skinner and Watson 2020).

The day after the Prime Minister of India announced a 21-day lockdown across India, in recognition that the lockdown would break the food supply chain, the Municipal Corporation of Ahmedabad City announced an innovative scheme which they called "Vegetables on Wheels" to deliver fresh vegetables from the wholesale markets to each ward of the city by e-rickshaws (electric 3-wheel rickshaws). The Ahmedabad Municipal Corporation (AMC) invited the Self-Employed Women's Organization (SEWA), a trade union of nearly two million women informal workers including fresh vegetable and fruit vendors, to partner with them. The scheme works like this (Chen and Shah 2020). The AMC issues a curfew pass to the designated vegetable vendors which allows them to go to the wholesale markets in the early morning to buy vegetables and fruit, which they transport back to their homes. The e-rickshaw drivers, provided and paid for by the AMC, pick up the vendors and their 
stock from the vendors' homes. The rickshaw drivers follow a route allocated to them by the AMC. At regular stops along the route, the vendors sell vegetables and fruits to local customers, mainly women, who queue up keeping a safe distance from one another. Although they had to protect the drivers, their customers, their families and themselves from contracting the virus, by practicing safe distancing, wearing masks and using sanitizers, each vendor was able to sell and make more each day through this scheme than she or he did prior to COVID-19.

\subsection{Waste Pickers}

Waste pickers are the primary collectors and sorters of waste who provide essential waste collection services and reclaim recyclable waste and, thereby, help to clean cities and reduce carbon emissions. Before COVID-19, most cities denied waste pickers access to waste and to dumps/landfills and many local authorities and the general public harassed waste pickers. But a growing number of cities have granted contracts to waste pickers to collect waste and reclaim recyclables, often providing the necessary infrastructure to collect, store and sort waste. During COVID19, waste pickers in most cities faced the closure of dumps and landfills as well as decreased demand/buyers and prices for recycled waste materials. However, some cities recognized waste pickers as essential service providers and allowed them to collect waste, but often without providing protective gear.

Two examples of local government support to waste pickers during COVID-19, one from Brazil and the other from India, suggest pathways to a better deal for waste pickers post-COVID. In Brazil, a long-standing waste and citizenship forum, involving representatives from government, the private sector, civil society and cooperatives of waste pickers, mapped whether waste pickers are receiving relief measures such as basic cash grants and food baskets; drafted an operational manual for resumption of segregated waste collection; and designed operational safety measures - for the collection, transportation, storing, sorting, processing waste-involving levels of protection (72-h storage of segregated waste at source, safe equipment and processes and individual PPE). The forum also mapped costs, taxes and other operating expenses of cooperatives of waste pickers to resume operations following the safety measures - in order to raise funds to meet these expenses (Dias et al. 2020).

Founded in 1993 in Pune City, India, KagadKach Patra Kashtakari Panchayat (KKPKP) is a trade union of waste pickers dedicated to establishing and asserting the contributions of waste pickers to the environment, their status as workers and their crucial role in the Solid Waste Management (SWM) of cities. In 2007, KKPKP formed a worker-owned cooperative of waste pickers, called $\mathrm{SWaCH}$, and negotiated a municipal contract for $\mathrm{SWaCH}$ to be allowed to collect waste where it is generated, whether in homes, offices or businesses. During the national COVID-19 lockdown in India, SWaCH continued door-to-door waste collection as this was seen as an essential service; negotiated successfully with the municipality for enhanced protective gear, and advocated for insurance cover and a special incentive payment, both currently tabled by the city administration for approval by the general body. 


\subsection{Relief to Recovery and Beyond}

The COVID-19 pandemic, the policy responses to it and the protests following the tragic murder of George Floyd have shown a bright sharp spotlight on systemic injustices and inequities around the world. This awareness, and the call for change by the protestors, represents an incredible opportunity to tackle these injustices and inequities. But while this defining moment represents an opportunity, it is also associated with significant risks.

It is very important to take advantage of this defining moment: to follow the call for racial and economic justice, for changing structures of discrimination and disadvantage. Post-COVID, we do not want the world to return to the Bad Old Deal which depended on exploited and degraded workers and over-exploitation of natural resources. We also do not want the world to return to a Worse New Deal: a very real threat as governments and corporations around the world seek to take advantage of the concern for public health and economic recovery to promote their own interests. We want the post-COVID world to usher in a paradigm shift, a Better New Deal, for all workers, informal and formal.

\subsection{Opportunity for Transformation}

The recognition of informal workers as frontline providers of essential goods and services should be translated into a new mindset towards informal workers-one that recognizes and values their contributions - and a new vision of the economy and of cities - one that recognizes and integrates informal workers and their activities into economic and urban plans. What is called for is a new mindset and vision that recognizes and protects the natural markets of street vendors and the waste collective and recycling services of waste pickers. What informal workers want and need is to be recognized and valued as workers who contribute to the economy; to have the right to social protection, both social assistance and social insurance; to have their livelihood activities integrated into and supported by local economic development and urban plans; to have their organizations recognized; and to have a voice in the rule-setting and policy-making processes that impact their lives and livelihoods.

\subsection{Threat of Negative Reversals}

However, there is a very real threat that the gains made by informal workers through years of struggle will be reversed. In cities around the world, informal workers are facing increased police harassment and violence, dislocation from their sources of work through privatization and their sites of work through evictions and increased discrimination and stigmatization as vectors of the virus. India has already witnessed signs of a Worse New Deal for informal workers. In the name of recovery from the virus, over 15 state governments in India have called for banning trade unions and labour regulations; and some have called for suspending the Trade Union 
Act for several years. In the name of public health measures, corporations in India have called for 12-h workdays. In order to benefit from the stimulus plans for micro, small and medium enterprises, larger businesses have lobbied to raise the threshold of investment and turnover to quality as medium-sized enterprises.

\subsection{Defining Moment}

There are three possible post-COVID scenarios for informal workers, most of whom are from poor households and disadvantaged communities.

- "Bad Old Deal"— - return to old normal which was bad for informal workers.

- "Worse New Deal"-reversal of pre-COVID gains made by informal workers.

- "Better New Deal"-post-COVID reforms to protect informal workers and enhance their livelihoods.

National, state and local governments around the world, including India, face a clear choice going forward: whether to protect the interests of the elites, including real-estate developers in cities, or to protect the rights of the poor, including the working poor in the informal economy. If the global community is to reduce poverty and inequality and to realize the 2030 Agenda and the Sustainable Development Goals, the choice is clear.

\section{References}

Bonnet, Florence, Joann Vanek, and Martha Chen. 2019. Women and Men in the Informal Economy-A Statistical Brief. Manchester, UK: WIEGO.

Chen, Martha, and Manali Shah. 2020. Selling Vegetables Door-to-Door during the Pandemic-cumLockdown in India: A Unique Collaboration between the Self-Employed Women's Association (SEWA), the Ahmedabad Municipal Corporation and Street Vendors. WIEGO Blog. Manchester, UK: WIEGO.

Crush, Jonathan S., and B.G. BruceFrayne. 2011. Supermarket Expansion and the Informal Food Economy in Southern African cities: Implications for Urban Food Security. Journal of Southern African Studies 37 (4): 781-807.

Dias, Sonia M., Abussafy, R., Gonçalves, J., Martins, J.P. 2020. Impacts of the COVID-19 Pandemic on Inclusive Recycling in Brazil https://www.wiego.org/publications/overview-impact-covid-19-pande mic-inclusive-recycling-brazil.

ILO. 2018. Women and Men in the Informal Economy: A Statistical Picture, 3rd ed. Geneva, Switzerland: ILO.

ILO. 2020. Impact of Lockdown Measures on the Informal Economy A Summary. May 2020 Factsheet. Geneva, Switzerland: ILO.

Narayan, Sudha. 2020. In this volume.

Raveendran, Govindan. Forthcoming. The Informal Economy in India-A Statistical Brief. Manchester, UK: WIEGO.

Skinner, Caroline and Vanessa Watson. 2020.” Planning and Informal Food Traders Under COVID-19: The South African case", Town Planning Review.

Publisher's Note Springer Nature remains neutral with regard to jurisdictional claims in published maps and institutional affiliations. 